\title{
Moving towards South-South International Health: debts and challenges in the regional health agenda
}

\author{
Por uma Saúde Internacional Sul-Sul: \\ dívidas e desafios na agenda de saúde regional
}

${ }^{1}$ Department of International Relations, Facultad Latinoamericana de Ciencias Sociales (FLACSO). Ayacucho 555, Centro. C1026AAC Buenos Aires Argentina. mbelen.herrero@gmail.com

\begin{abstract}
The aim of this paper is twofold. First, it aims to investigate the increased interest in health as an important dimension of the foreign policy and diplomatic concerns together with the emergence of a new framework for regional health integration and regional health diplomacy. Second, it seeks to understand the role and practices of new regional blocs in the field of health and whether they are conducting to the emergence of new strategies for addressing health regional policies in South America. The regional policy process relates to health as a right. Thus, some practices and processes in social policy are setting new standards for political and social cohesion in the construction of new regionalism. Health crosses national, regional, and global agendas in a multi-directional fashion, rather than via one-way, top-down policy transfer. A special feature of Unasur is upholding regional health sovereignty despite the unique fact that member countries retain national autonomy. Unasur has projected foreign policy that promotes social values in ways that seem innovative. Experience as Unasur shows that regional organisms can become a game changer in global diplomacy and an influential actor in the international agenda.
\end{abstract}

Key words Right to health, Health inequalities, Global health, Diplomacy, International cooperation
Resumo O objetivo deste artigo é duplo. Primeiro, ele tem como objetivo investigar o aumento do interesse em saúde como uma dimensão importante da política externa e de preocupações diplomáticas, bem como o surgimento de novos quadros de integração e diplomacia da saúde regional. Em segundo lugar, procura compreender o papele as práticas de novos blocos regionais no campo da saúde e se eles estão conduzindo ao aparecimento de novas estratégias para lidar com as politicas regionais de saúde na América do Sul. O processo de política regional refere-se à saúde como um direito. Assim, algumas práticas e processos de política social estão estabelecendo novos padrões de coesão política e social na construção de um novo regionalismo. Além disso, a saúde ascende agendas nacionais, regionais e globais de uma forma multidirecional. Uma característica especial que a Unasul propõe é de uma soberania regional da saúde, apesar do fato de os países membros manterem sua autonomia nacional. Neste contexto, a Unasul tem projetado uma política externa que promove os valores sociais a partir de outro enfoque. A experiência como Unasul mostra que os organismos regionais podem se tornar um trocador de jogo na diplomacia global e um ator influente na agenda internacional.

Palavras-chave Direito à saúde, Desigualdades em saúde, Saúde global, Diplomacia, Cooperação internacional 


\section{Introduction}

Social policy rose to a high priority of countries, after the results of neoliberal policies, in a context of increased social inequalities, lack of access to health systems and expansion of social exclusion. Thus, social policies, and particularly health policies, become essential strategies to combat poverty and reduce inequalities.

Amidst the market globalization, health emerged in the XXI century on the global political agenda as an issue that could only be effectively addressed through cooperative efforts. Throughout migration, war, and epidemics periods, globalization has allowed health to transcend national boundaries, causing political and economic impacts on a global scale. Good health improves living conditions, while better living conditions contribute to good health. A better life and good health are both essential elements towards the quality of civic life, peace, security, and governance. Health has acquired an important place in international relations and diplomatic concerns and has come to play a key role in the foreign policy agenda in the last decades. Fidler ${ }^{1}$ calls this moment the global health 'revolution' to denote the increasing health role in foreign policy. Health became an essential part of the equation of international relations, and it has generated an unprecedented hike in funding and similarly growing the influence of policymakers, activists, and philanthropists who claim health as a foreign policy issue of first-order importance ${ }^{1}$.

The role of health in international cooperation is dynamic, and this agenda is constantly in expansion according to the needs of governments and changing development models. In this scenario, health improvements depend increasingly on the directions of the globalization processes, international cooperation, and regional integration. Regionalism today represents a conglomerate of commercial, political, and social projects that revolve around new principles of solidarity and regional autonomy, and they are an opportunity to synchronize the inclusion of policies at multiple scales. In this context emerged a new framework of regional health integration and regional health diplomacy, with a growing centrality of regional organisms in the international health agenda. This process involved new opportunities and challenges that must be overcome.

This paper attempts to serve as a basis for discussion about the role of regional integration in the new health diplomacy, how regional policies can influence national and global agendas and whether it is possible to move towards a SouthSouth International Health, always with the horizon of health as a right.

\section{Recovering the region throuth regional integration in Latin America}

The political, economic, and social changes in the region have always given rise to a distinct form of regional integration, in order to meet the needs of the specific countries involved. When trade-regional organizations were set up in the 1990s in South America, cross-border projects on regulations for health, education, and labor were embedded, for example, in Andean Community and Mercosur. A decade later, based on the principle of new alliances, New Leftist leaders began to redefine the contours of regional governance. The effort to recover the potential development of South America was a clear manifestation of a "change of era". This change gives rise to new policies and agreements in the region based on different principles, standards, and systems than those which had been promoted until that point. Practices focusing on social policy and new standards for political and social cohesion in the construction of regionalism were setting ${ }^{2}$.

Latin America became a platform for the emergence of regionalism which would incorporate the normative dimensions of a new era and to go beyond the standards set by the United States on trade integration. The importance of these processes is a re-politicization of the region, giving rise to new political organizations and regional projects in which States, social movements, and leaders began to interact and build new understandings of the regional space ${ }^{2}$.

The region in these last decades represented a cluster of social welfare integration projects and policies that encompassed strategies to recover the principles of cooperation and solidarity. In this scenario, not free from conflicts or contradictions, the terms of regional governance were redefined, and each project faced substantially with divergent views of what regionalism is and why it exists. These new spaces arise from the need to recover the region and embrace global solidarity, instead of global governance and liberal, market-driven economic policies. South America became a space for contention and contestation, as well as an arena of consensus-building ${ }^{3}$.

New catalysts, at the national and international level, forged new opportunities to redefine objectives of regional political economy and forms of collective action. Health is a paradig- 
matic example of regional cooperation, as a possibility of expanding chains of public policy ${ }^{4}$. The new process of globalization has undoubtedly introduced a new societal climate of worldwide interdependence, including in the health status of populations. The increasing role of health in international relations, as an important dimension of the foreign policy and diplomatic concerns, has in turn given rise to a number of influential regional and international policies and governing organisms. Such process strengthened regional and international integration while helped countries to propose initiatives in international cooperation in health that could not have resulted successfully if attempted individually.

Such unpacking of regions allows us to move away from one-dimensional views that posit regional cooperation as mainly led by the imperatives of the global economy ${ }^{5}$. Beyond the commercial emphasis leading the regional integration projects, a new political-economic context in South America opened space for the emergence of new links to regional policies claiming, and perhaps re-inventing principles of solidarity and collectivism that differs strongly from previous regionalist projects. To the sanitarian and redistributive challenge, the new experiences of regional integration in health added a political one, of designing regional strategies towards better access to health through international negotiations and the improvement of human and industrial capacity in South America. The case of the Union of South American Nations (Unasur), born in 2008 as a political block ${ }^{6}$, was an example of this and accounted for the links between regional integration and social development, and what could be considered new forms of regionalism as a process of collective action within the region and for the region ${ }^{4}$.

\section{Regional integration and a rights-based approach to health in South America}

In many South America countries, social and health policies were key axes of the welfare state. The concept of health has always been related to citizens' rights and has been institutionalized as part of a democratic right, a tool for inclusion and a milestone in the welfare state ${ }^{7}$. In this sense, health has played a key role in the democratic ethos of the region. There is a strong background of sanitarism and social medicine, which developed an approach linked to social epidemiology, collective health, and social determinants of health ${ }^{8}$. After the results of neoliberal policies, in terms of population's impoverishment, increased social exclusion and lack of access to health systems, the regional picture was becoming increasingly complex, challenging the notion of regionalism and US-led liberal governance

These points are key to understand why an essentially political body such as Unasur has taken health matter on the road to building a new regionalism, becoming, in the context of social policies, a tool towards self-reliant development, and "a regional cause" against external influence and the approach of international organizations or donor partners (one of the principle flags of the organism). Another point that makes this organization particularly interesting is its vision of regionalism and integration. Building on existing commercial agreements (Mercosur and the Andean Community) it strengthened new areas of regional cooperation beyond trade. Unasur, by the nature of its constitution itself, took up health as a main political issue from the start, and therefore it was also incorporated at the level of norm promotion ${ }^{9}$. The Health Council ${ }^{6}$ was one of the first to be created together with the Council of Defence and made great progress ${ }^{10}$, and the practice of member states at Unasur Health makes health one of the most dynamic areas of regional cooperation. This council made great advances in drug policies, training of human resources, and south-south cooperation ${ }^{9}$.

Despite deep differences in the health systems of its members, Unasur has placed its focus on the right to health and health sovereignty, through a strong sense of collective action and political integration, including in some regulatory frameworks. What's more, while traditional regional bodies or multilateral organisms have been following a strategy to address health, but focused on a disease by disease ${ }^{11}$ (i.e HIV, malaria and tuberculosis), Unasur promotes a move towards horizontal cooperation and cross-cutting policies. In this context, and with the universalization of health systems as a horizon, Unasur policies are linked to access to health and not addressing disease-by-disease, moving away from the traditional and vertical model of donors and recipients 9 This was translated, even when they were incipient, into initiatives to unpack the social determinants of health, the promotion of public health schools and the universal health systems ${ }^{12}$.

A special feature of Unasur was to propose the construction of a regional identity without the need for member countries to delegate some of their sovereignty. Impressively, it managed to establish itself as a regional integration organi- 
zation in which regional level interests are valued more than the power of the overseeing body and are superior to the individuality of the member countries. Unlike the European Union (EU), Unasur is not a supranational organization, and its member countries, therefore, do not surrender national sovereignty under its governance. Nevertheless, Unasur has continually succeeded in pushing health issues to the forefront of national agendas. In this sense, another interesting issue to discuss is the regional policy process and its results in terms of health diplomacy. Through Unasur, it is possible to see the three levels in which this organism operates and in which the emergence, diffusion, and implementation of norms are promoted as well: national, regional and global level ${ }^{9}$. The regional/national channel is a two-way street. Ideas for regional health policies are also disseminated and reconstructed from the national to the regional level, and vice versa, in a two-way process. The regional level of governance acts as a hinge which enables coordinated tabling of global initiatives. This is central in terms of health diplomacy and the regional policy process. Once the initiatives emerge, some of them are taken to the global sphere with the aim of promoting specific issues on the international health agenda. In doing so, Unasur seeks to secure a voice in global health and gain political prominence in terms of health diplomacy ${ }^{4}$. Gaining a voice in global diplomacy is a central driving force that also allows identity building 3 . The intervention of Unasur in the topic of access to medicines is an example of an issue that has been well-worked out from its regional base and it is one of the interventions that confirm the role of the new regional organisms in norm development on the global stage.

It seems a quiet revolution in health diplomacy in the region that promotes a movement toward horizontal cooperation and technical support, away from what its leaders view as an outmoded vertical model of donors and recipients. Although the idea of social policy through regionalism is hardly 'new' what are new are both the content and the ground laid for institutional cooperation. This is a major policy difference with former cooperation in trade-led agreements which promoted pro-market provision within countries. In such agreements, health enjoyed a residual status at best, the agenda focused on sanitary security rather than health promotion as such $^{3}$. Building on those stepping stones but in a more assertive political environment, the new regional integration in health experiences em- braced health, both as integral parts of cooperation and as a part of the rights agenda, for which the suited governance mechanisms need to be laid out. Despite the own limitations and barriers of Unasur since its creation, that merit a deep reflection and discussion, these elements are some of the main added values of this organism and probably an innovative contribution in terms of a new regional integration in health.

\section{Winds of change in the region}

Alongside the changing globalization process, international health agenda has become increasingly more comprehensive and complex. Although globalization seems to challenge traditional distinctions between national and foreign affairs, the role of sovereign states is still the cornerstone. Markets and trade are indeed controlled by the developed world, whose influence is visible in the geopolitical map of international health. Thus, the relationships between States and, actions of diplomacy and cooperation in health became critical nodes in international health. This contributes to the emergence of a new framework for regional integration in health, innovative regional practices and methods and implementation of new strategies for addressing health regional policies ${ }^{13}$.

Some points are important in this "winds of change" in the region. First, regional organizations are acquiring a central role in the international health agenda. Secondly, the development of regional health policy has a potential impact on regional and national contexts. And thirdly, there is more assemblage of norms oriented in a multi-directional fashion, rather than via one-way, topdown policy transfer, allowing health crosses national, regional, and global agendas, addressing debts in health through innovative strategies. This means that the regional level boosts the national level of governance and potentially enables change in the balance of forces within countries, while at the same time the sharing and pooling of capacities open roads to influence global health diplomacy. As for the national, to the global level, this mechanism helps to reduce asymmetries between countries and gives smaller countries a voice and an opportunity to participate in the global health agenda. This cycle of the norms constitutes a window of opportunity to introduce new issues in the international health agenda ${ }^{14}$.

Without even a trace of intending a one size fits all approach, cooperation faces numerous challenges in a region where business actors 
fiercely resist change and the social determinants of health prevail, an issue that shows disparities in income, gender, nutrition, clean air, and clean water. While inequality reduction is at the forefront of development in South America and much has been achieved over the last decade, countries still face a double burden of disease and deep inequalities ${ }^{12}$. South-South cooperation seeks to tackle health from a more structural point of view, focusing on social determinants and reducing health inequalities ${ }^{13}$. During the last decades, some practices and processes in social policy were setting new standards for political and social cohesion in the construction of SouthSouth regionalism. Experience as Unasur shows that some regional blocks can eschew one-way, top- down policy transfer, and what is more, that regional organisms can become a game changer in global diplomacy and an influential actor in the international agenda.

Regional integration and international cooperation are at the forefront of not only promoting the well-being of individuals but also by providing tools to empowering nations towards being successful contributors to the global community. What will happen to the strides made in regional integration with contradictory economic and political schemes introduced? Will the region crack under the pressure and revert to a commercial focus as seen prior to the 1990s? It is of utmost importance to continue researching international health, the role of different actors involved, how they build a global agenda, and how to move towards a South-South International Health which should always promote equality, peace, interculturality, and social justice above all.

\section{Conclusions}

Given the influence of the European Union as a template, it has been difficult to consider the effectiveness of a regional integration organization without the delegation of sovereignty and the creation of a supranational instance. However, during the last decades, some practices and processes in social policy were setting new standards for political and social cohesion in the construction of South-South regionalism. A special feature of Unasur is upholding regional health sovereignty despite the unique fact that member countries retain national autonomy. Experience as Unasur shows that regional organisms can become a game changer in global diplomacy and an influential actor in the international agenda. In this way, positive lessons can be drawn from the integrative processes that Unasur has used to promote regional health diplomacy. New political and economic purposes are taking form and fighting for the center stage. The study of the new geopolitics scenario in the region is necessary in order to analyze changes in the form and content of regional governance, as a product of the new political-economic and social situation.

\section{Acknowledgments}

The author warmly thanks Diana Tussie and Marcela Belardo for all their very helpful feedback on earlier versions of this paper. The author also thanks Adriana Greco for her invaluable contribution to the translation and organization of this paper. 


\section{References}

1. Fidler DP. Caught between paradise and power: public health, pathogenic threats, and the axis of illness. $M c$ George Law Rev 2004; 35(45):45-104.

2. Riggirozzi P, Tussie D, compilers. The Rise of Post-Hegemonic Regionalism: The Case of Latin America. Dordrecht: Springer; 2012.

3. Herrero MB, Tussie D. Unasur Health: A quiet revolution in health diplomacy in South America. Glob Soc Policy 2015; 15(3):261-277.

4. Riggirozzi P. Regionalism through social policy: Collective action and health diplomacy in South America. Econ Soc 2014; 43(3):432-454.

5. Tussie D. Latin America: Contrasting motivations for regional projects. Rev Int Stud 2009; 35(1):169-188.

6. Union de las Naciones Suramericanas (Unasur). South American Union of Nations Constitutive Treaty, 2008. [cited 2016 oct 3]. Available at: http://www.comunidadandina.org/unasur/tratado_constitutivo.htm

7. Tobar F. Breve historia de la prestación del servicio de salud en la Argentina. Med Sanitaria 2001; 1: 22.

8. Almeida C. Saúde, política externa e cooperação sul-sul em saúde: elementos para a reflexão sobre o caso do Brasil. In: Fundação Oswaldo Cruz. A saúde no Brasil em 2030 - prospecção estratégica do sistema de saúde brasileiro: desenvolvimento, Estado e políticas de saúde. Rio de Janeiro: Fiocruz/Ipea/Ministério da Saúde/ Secretaria de Assuntos Estratégicos da Presidência da República; 2013. p. 233-327.

9. Herrero MB, Loza J. Building a regional health agenda: a rights-based approach to health in South America. Glob Public Health 2017; 1-13.

10. Coitiño A. Análisis del fenómeno de los procesos regionales de integración en salud como actores emergentes de la diplomacia de la salud global: el caso Unasur. Washington: PanAmerican Health Organisation; 2014. Programas de Líderes de Salud Internacional.

11. Harman S. Global Health Governance. New York: Routledge; 2012.

12. Giovanella L, compiler. Atención primaria de salud en Suramérica. Rio de Janeiro: ISAGS Unasur; 2015.

13. Informe de la Cooperación Sur Sur en Iberoamérica, 2016. Secretaria General Iberoamericana, Madrid". [acceso 2017 ene 20]. Disponible en: http://www.cooperacionsursur.org/images/InformeCSS-2016.pdf

14. Kingdon JW. Agendas, Alternatives and Public Policies. Boston: Longman; 2011.

Artigo apresentado em 21/09/2016

Aprovado em 28/11/2016

Versão final apresentada em 06/02/2017 